\title{
Glosa do „Tû-tû” Alfa Rossa
}

Trudno nie zgodzić się ze słowami Andersa Wedberga, że dla zdrowego rozsądku prima facie wstrząsające może być dopuszczenie do prawniczego dyskursu terminów, które same w sobie nie posiadają żadnego sensu ${ }^{1}$. W zaprezentowanym artykule pt. „Tûtû" duński filozof prawa Alf Ross dowodzi właśnie, iż pojęcia, na których opiera się całe prawo - takie, jak np. „uprawnienie”, „roszczenie”, „własność” - są wyrazami pozbawionymi znaczenia oraz odniesienia semantycznego, $\mathrm{w}$ istocie będącymi zaledwie użytecznymi narzędziami służącymi jako metoda prezentacji (technique of presentation). Tekst ten jest bodaj najbardziej znaną i najszerzej komentowaną pracą Rossa. Pierwotnie opublikowany został w języku duńskim w 1951 r., sześć lat później zaś jego angielska wersja ukazała się na łamach periodyku „Harvard Law Review”.

„Tû-tû” z pewnością nie można odmówić błyskotliwości oraz oryginalności zarówno pod względem formy, jak i treści. Autor dochodzi do zaskakujących wniosków za pomocą analogii, porównując prawniczy sposób myślenia, a także jurydyczną terminologię do zwyczajów i słów funkcjonujących w zmyślonym przezeń plemieniu Noît-cif. Można jednakże w tym miejscu zadać pytanie o prawdziwość i niepodważalność Rossowskich konkluzji. Jak się wydaje, koncepcja tû-tû nie jest bowiem bezdyskusyjna. Kierowane wobec niej zarzuty opisane zostały w wydanej w 2016 r. książce Katarzyny Eliasz pt. „Realistyczna koncepcja prawa Alfa Rossa”. Pozycja ta zasługuje na uwagę, albowiem jest pierwszą polską monografią poświęconą temu myślicielowi, stanowiącą próbę kompleksowej analizy jego poglądów. Szczegółowa ocena stanowisk krytycznych co do „Tû-tû” przekracza ramy niniejszego komentarza, tym niemniej warto przytoczyć przynajmniej jedną z ciekawszych uwag, sformułowaną przez Bartosza Brożka w anglojęzycznym artykule „On tû-tû"3.

Polski filozof, przyjmując postawę opozycyjną względem Rossa, zauważa iż wykorzystując zaproponowaną przez niego konstrukcję, dowodzić można braku odniesienia semantycznego niemalże każdego słowa. Brożek posługuje się między innymi następują-

\footnotetext{
${ }^{1}$ Podaję za A. Ross, Tû-Tû, Harvard Law Review vol. 70, Issue 5, March 1957, s. 823.

${ }^{2}$ K. Eliasz, Realistyczna koncepcja prawa Alfa Rossa, Warszawa 2016, s. 103-106.

${ }^{3}$ B. Brożek, On tĥ-tû, Revus. Journal for Constitutional Theory and Legal Philosophy 2015, vol. 27. Tekst dostępny również za https://revus.revues.org/3426 (07.08.2017).
} 
cym przykładem: „jeśli x jest mango, to x jest jedzeniem”. Zakładając, że istnieje społeczna norma mówiąca: „Jeśli $\mathrm{x}$ jest jedzeniem, to x powinno być dzielone między członkami wspólnoty”, musimy dojść do wniosku, iż słowo „jedzenie” pełni funkcję „tû-tû" i - w konsekwencji - nie posiada żadnego znaczenia. Podobnie argumentować można na rzecz braku odniesienia semantycznego terminu „totemiczne zwierzę”. Tymczasem przecież Ross uznaje, że - w przeciwieństwie do „tû-tû”, „własności”, „roszczenia” - słowa takie, jak „,totemiczne zwierzę”, ,jedzenie”, „wódz” posiadają swoje dokładnie określone desygnaty. Zdaniem Duńczyka wyrazy z pierwszej grupy służą wyłącznie jako użyteczne narzędzie systematyzacji prawa, z drugiej zaś mają prawdziwe znaczenie oraz zdefiniowane odniesienie semantyczne. Z takim podejściem polemizuje Brożek, który stoi na stanowisku, iż błędna jest konkluzja o braku odniesienia semantycznego niektórych terminów używanych w prawie, a co więcej - za nieprawdziwe uznać trzeba także stwierdzenie, że „pośrednicząca idea uprawnień” to zaledwie narzędzie pomocnicze dla „metody prezentacji”. Ocenę słuszności wszystkich powyższych uwag, jak również samej koncepcji „tû-tû” pozostawiamy Czytelnikowi.

„Tû-tû” Alfa Rossa odczytywać należy w kontekście założeń skandynawskiego realizmu prawniczego, którego Duńczyk jest - obok Axela Hägerströma, Andersa Lundstedta i Karla Olivecrony - wybitnym przedstawicielem. Zwolennicy tego kierunku filozoficznoprawnego prezentują odnośnie do prawa podejście naturalistyczne, krytyczne zarówno wobec pozytywizmu prawniczego, jak i prawa natury. Wyodrębnić można znaczące różnice pomiędzy poszczególnymi myślicielami, niemniej jednak jedną z kwestii im wspólnych niewątpliwie jest zgoda co do fikcyjności pewnych prawniczych terminów, będących - ich zdaniem - spuścizną po początkach naszej cywilizacji oraz przejawem myślenia magicznego, prymitywnego. $Z$ tej perspektywy tekst Rossa uznać trzeba zatem za wręcz wzorcowy i zawierający w sobie najważniejsze idee skandynawskich prawniczych realistów. Ponadto nie ulega wątpliwości, że koncepcja „tû-tû” odgrywa centralną rolę w całej filozofii jej twórcy, o czym świadczy chociażby fakt, iż odwołuje się on do niej również w innych swych dziełach. W tym kontekście wymienić można między innymi książkę „On Law and Justi$\mathrm{ce}^{\text {”" }}$, w której Ross ponownie przywołuje tezy z artykułu „Tû-tû”, dodając do nich szerszy komentarz, lub pracę „On Guilt, Responsibility, and Punishment”, w której z kolei „odpowiedzialność” ujęta zostaje przez filozofa właśnie jako koncept „tû-tû”.

\footnotetext{
${ }^{4}$ A. Ross, On Law and Justice, Clark 2004, s. 170-189.

${ }^{5}$ A. Ross, On Guilt, Responsibility and Punishment, University of California Press, 1975, s. 20-24.
} 
Jak zatem wykazano, artykuł Rossa jest istotny z punktu widzenia podstawowych propozycji realizmu prawniczego. Nie został on jednakże jak dotąd przełożony na język polski, sam jego autor natomiast - jak sądzimy - nie jest postacią znaną szerszemu odbiorcy. Być może więc tłumaczenie zamieszczone w aktualnym numerze czasopisma „Societas et Ius" przyczyni się do popularyzacji myśli duńskiego filozofa. 